Published by LPMP Imperium

Journal homepage: https://ejournal.imperiuminstitute.org/index.php/JMSAB

\title{
ANALISIS PENGARUH PEMBANGUNAN INFRASTRUKTUR TRANSPORTASI TERHADAP PRODUK DOMESTIK REGIONAL BRUTO KABUPATEN WAY KANAN PROVINSI LAMPUNG
}

\author{
${ }^{1}$ Febriansyah, ${ }^{2}$ Gustaf Gautama \\ 1Manajemen, Fakultas Ekonomi, Universitas Saburai \\ Jl. Imam Bonjol No. 486 Langkapura, Way kanan. \\ 2Teknik Sipil, Fakultas Teknik, Universitas Saburai \\ Jl. Imam Bonjol No. 486 Langkapura, Way kanan. \\ Email Korespondensi : febriansyahali9@gmail.com
}

\begin{abstract}
The availability of inadequate and quality transportation infrastructure positively affects a region's gross domestic product (GRDP) to below. This study aims to analyze the influence of transportation infrastructure development, namely road infrastructure, seaport infrastructure and airport infrastructure on Way Kanan District GRDP. The research method used in this study is a quantitative method. The results of multiple regression calculations show that 1) the road infrastructure has a significant number of 0.010 below 0.05; meaning that the independent variable has a substantial effect on GRDP. 2) seaport infrastructure, the considerable amount is 0.309 above 0.05; saying that these variables have not significantly affected gross regional domestic products. 3) Airport infrastructure, a significant number of 0.093 above 0.05; it means that the variable has not changed the GRDP. While the contribution of the research is a reference in development policies, especially the development of transportation infrastructure to increase the GRDP of Way Kanan District.
\end{abstract}

Keywords: Roads Infrastructure, Seaport Infrastructure, Airport Infrastructure, and Gross Regional Domestic Product.

(C) The Author(s) 2021

DOI: $10.36407 /$ jmsab.v4i2.422

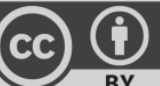

CC BY: This license allows reusers to distribute, remix, adapt, and build upon the material in any medium or format, so long as attribution is given to the creator. The license allows for commercial use.

\section{Research \\ Paper \\ Management \\ Received: 05 \\ Agustus 2021 \\ Accepted: 04 \\ November \\ 2021 \\ Online: 31 Des \\ 2021

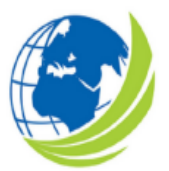

Jurnal

Manajemen

Strategi dan

Aplikasi

Bisnis,

Vol 4, No. 2,

2021,

pp. 508 - 518

eISSN 2655-

237X 


\section{PENDAHULUAN}

Pembangunan infrastruktur transportasi merupakan bagian integral dari pembangunan nasional. Oleh karena itu, pembangunan infrastruktur diyakini sebagai motor pembangunan suatu kawasan, termasuk pembangunan industri. Berbagai upaya telah dilakukan pemerintah untuk menyediakan fasilitas dan layanan infrastruktur yang berkualitas, baik dalam bentuk pengaturan dengan kerangka regulasi maupun kerangka investasi melalui rehabilitasi dan peningkatan kapasitas fasilitas infrastruktur yang rusak, serta pembangunan baru. Kerangka kebijakan regulasi dan kerangka investasi diharapkan akan dapat meningkatkan ketersediaan fasilitas dan layanan infrastruktur.

Peningkatan pertumbuhan PDRB yang tinggi, sangat dipengaruhi oleh tersedianya infrastruktur transportasi pada suatu wilayah. Namun dari sisi penawaran (side supply), pemerintah terkendala dengan minimnya investasi (dana) untuk pemeliharaan maupun pembangunan baru untuk infrastruktur transportasi. Sedangkan disisi lain, permintaan (side demand) terhadap infrastruktur transportasi sangat tinggi karena jumlah penduduk Kabupaten Way kanan bertambah padat. Dengan demikian moda tranportasi bertambah pula untuk memenuhi permintaan pengguna jasa pengangkutan.

Walaupun ada upaya untuk mempercepat pembangunan infrastruktur dan/atau prasarana transportasi, memerlukan waktu yang tidak singkat dan dengan biaya yang besar. Oleh karena itu, menuntut adanya fokus serta keseriusan dalam mewujudkannya. Untuk menjamin bahwa pembangunan proyek tersebut dapat berjalan, mulai dari tahapan persiapan hingga operasi secara berkelanjutan diperlukan suatu kebijakan yang sinergis, solid, konsisten, dan tepat waktu dengan tetap menjaga kaidah-kaidah good governance.

Upaya untuk mencapai sasaran tersebut, maka diperlukan suatu perencanaan seperti rehabilitasi, pemeliharaan dan menyelesaikan pembangunan infrastruktur transportasi dengan mempertimbangkan efektivitas biaya dan kendala waktu serta faktor lainnya seperti, teknologi dan konsumen yang dilayani. Di samping itu, harus mempertimbangkan aspek peraturan dan perundang-undangan yang berlaku, seperti pelaksanaan otonomi daerah dan perimbangan keuangan antara pusat dan daerah. Melalui suatu perencanaan yang matang, maka pembangunan infrastruktur transportasi harus menjadi prioritas utama, terutama untuk menunjang pembangunan ekonomi secara makro maupun secara mikro yang lebih meningkat dan berkualitas.

Salah satu langkah yang telah ditempuh oleh pemerintah untuk meningkatkan kapasitas infrastruktur yang terbatas, terutama di tingkat daerah-daerah miskin / tertinggal, yaitu yang dikenal dengan konsep Master Plan Percepatan dan Perluasan Ekonomi Indonesia (MP3EI). Melalui MP3EI, pembangunan infrastruktur di Indonesia seolah mendapat kembali momentum. MP3EI dimaksudkan untuk membuat terobosan (breakthrough) dan bukan "business an usual" untuk mendorong terwujudnya pertumbuhan ekonomi yang tinggi, berimbang, berkeadilan, dan berkelanjutan. MP3EI kini menjadi panduan bagi proses perencanaan nasional yang menggabungkan konsep perencanaan kewilayahan dan sektoral.

Maksud dan tujuan pokok daripada MP3EI tidak lain adalah memperkokoh landasan perekonomian di daerah, melalui usaha untuk memacu/meningkatkan Produk Domestik Regional Bruto (PDRB). Dengan kata lain, keberhasilan pembangunan di daerah, salah satu tolok ukurnya adalah tingkat capaian PDRB-nya. Peningkatan PDRB yang signifikan tentu akan berdampak langsung pada Produk Domestik Bruto (PDB). Sehubungan dengan itu, maka laju PDRB sangat ditentukan juga oleh pembangunan infrastruktur transportasi yang memadai dan handal di daerah.

Infrastruktur merupakan roda penggerak pembangunan ekonomi, baik secara nasional maupun regional/daerah. Dari alokasi pembiayaan publik dan swasta, infrastruktur dipandang sebagai lokomotif pembangunan nasional dan daerah. Secara ekonomi makro 
ketersediaan dari jasa pelayanan infrastruktur memengaruhi marginal productivity of private capital, sedangkan dalam konteks ekonomi mikro, ketersediaan jasa pelayanan infrastruktur berpengaruh terhadap pengurangan biaya produksi. Disamping itu, infrastruktur juga berpengaruh penting bagi peningkatan kualitas hidup dan kesejahteraan manusia, seperti adanya peningkatan produktivitas tenaga kerja, akses terhadap lapangan kerja, dan peningkatan stabilisasi makro ekonomi, yaitu keberlanjutan fiskal, berkembangnya pasar kredit dan pengaruhnya terhadap pasar tenaga kerja.

Peran lainnya adalah infrastruktur sebagai prasarana jaringan dasar dari keberadaan dari suatu kota atau wilayah merupakan faktor penting didalam keberlangsungan dan pertumbuhan kota atau wilayah. Apabila dalam penyediaan dan pemeliharaan infrastruktur transportasi tidak dilakukan dengan baik, maka jaringan kota atau simpul kegiatan perkotaan didalam suatu wilayah menjadi terganggu, yang selanjutnya berdampak kepada degradasi sistem ekonomi dan sosial masyarakat. Hal ini, menunjukkan bahwa keberadaan infrastruktur merupakan modal utama suatu wilayah untuk maju dan berkembang dalam usaha memacu dan merangsang perekonomian, yang signifikan, baik lingkup makro maupun mikro. Dengan kata lain, tanpa infrastruktur jalan, infrastruktur pelabuhan darat, dan infrastruktur bandar udara yang memadai, maka kemajuan pembangunan di semua aspek kehidupan manusia menjadi tidak berkembang (subsistence).

Sehubungan dengan itu, maka tidak dapat dipungkiri bahwa infrastruktur transportasi merupakan urat nadi bagi suatu wilayahyang sangat berperanuntukmendorong percepatan perkembangan suatu wilayah agar dapat menggerakkan perekonomian melalui siklus aliran barang maupunmobilitas manusia dari daerah yang satu ke daerah yang lain.

Dengan adanya ketersediaan infrastruktur transportasi merupakan salah satu penyebab didalam memberikan daya eksternalitas yang sangat besar untuk peningkatan kegiatan perekonomian dalam suatu wilayah tertentu, secara bersimultan. Dalam artian, bahwa pembangunan infrastruktur transportasi mutlak telah tersedia, barulah pembangunan infrastruktur lainnya akan bisa berlangsung dan berkembang dengan baik termasuk pembangunan aspek kehidupan lainnya.

Pendapat di atas didukung oleh beberapa hasil penelitian, dimana cukup banyak studi yang mengungkapkan bahwa pembangunan infrastruktur sangat berperan dan mempengaruhi pertumbuhan ekonomi suatu negara atau wilayah. Bahkan studi yang dilaporkan oleh World Bank, bahwa elastisitas Produk Domestik Bruto (PDB) terhadap infrastruktur transportasi di suatu negara adalah memberikan efek multiplier sebesar $7 \%$ sampai dengan $44 \%$, suatu variasi angka yang cukup signifikan. Pembangunan infrastruktur transportasi yang memadai diyakini sebagai faktor penentu dalam mendorong PDRB.

Pertumbuhan PDRB tidak akan pernah berkembang dengan cepat dan maju, bila pembangunan infrastruktur transportasi, masih sangat terbatas. Tersedianya infrastruktur transportasi pada suatu wilayah, akan menyebabkan efek berantai terhadap pembangunan ekonomi lainnya. Efek berantai ,yang dimaksudkan adalah efek yang ditimbulkan karena adanya kegiatan pembangunan sebelumnya sehingga mengakibatkan adanya rangkaian kegiatan lanjutan di bidang ekonomi secara terus-menerus.

Akibat adanya efek berantai yang ditimbulkan dari ketersedian infrastruktur transportasi maka berbagai usaha atau industri, baik industri Usaha Kecil dan Menengah (UKM) maupun industri yang berskala besar, akan terus bertumbuh dan meningkat dengan cepat. Dengan adanya industri UKM dan industri berskala besar akan ada perluasan usaha sehingga dapat menciptakan lapangan kerja yang luas bagi para pengangguran sehingga ada pendapatan riilnya bagi para pekerja. Disamping itu, dengan tersedianya infrastruktur transportasi, maka pelayanan publik terhadap masyarakat oleh pemerintah semakin meningkat secara efektif, efisien, dan ekonomis. Semua ini tentunya akan berimplikasi pada tingkat pertumbuhan ekonomi regional Kabupaten Way Kanan yang makin meningkat dari tahun ke tahun. 
Terkait infrastruktur transportasi yang ada di Kabupaten Way kanan, pemerintah telah mencanangkan percepatan pembangunan infrastruktur transportasi agar tingkat pertumbuhan PDRB semakin meningkat. Salah satu langkah yang ditempuh adalah melibatkan sektor swasta untuk ikut serta dalam pembangunan infrastruktur rmelalui penanaman modal (investasi), baik pihak asing maupun nasional. Namun, bidang usaha di sektor infrastruktur transportasi di dalam negeri, khususnya di daerah belum ada minat (keuntungan yang menggiurkan) bagi pihak swasta. Hal ini dikarenakan, tingkat pengembalian modal butuh waktu yang cukup panjang sehingga pemerintah menjadi pemeran utama/tunggal untuk pembangunan atau pemeliharaan infrastruktur transportasi. Kabupaten Way kanan, sebagai salah satu tempat kegiatan perekonomian di Provinsi Lampung, butuh ketersediaan infrastruktur transportasi yang sangat memadai dan berkualitas. Berarti, pembangunan infrastruktur transportasi yang meliputi jalan, pelabuhan dan bandar udara harus disinergikan dan proporsional serta ditingkatkan pembangunannya. Dengan demikian, ketiga jenis infrastruktur transportasi tersebut saling mendukung dan terkait akan dapat menciptakan eksternalitas ekonomi dalam rangka meningkatkan pertumbuhan ekonomi yang tinggi, baik secara kualitas maupun kuantitas.

Berhubungdenganadanyaketerbatasan Anggaran Pendapatan dan Belanja Negara (APBN) maupun Anggaran Pendapatan dan Belanja Daerah (APBD) Kabupaten Way kanan, maka akan berdampak pada kapasitas infrastruktur transportasi yang terbatas. Sedangkan untuk mengimbangi keterbatasan infrastruktur yang ada diperlukan anggaran yang optimal. Namun, yang terjadi adalah peningkatan permintaan tidak berbanding lurus dengan ketersediaan infrastruktur transportasi yang dibangun oleh Pemerintah Pusat dan Kabupaten Way kanan.

Kondisi demikian tentunya berdampak pada pembangunan dan/atau pemeliharaan infrastruktur transportasi yang terbatas sehingga memengaruhi Produk Domestik Regional Bruto (PDRB) Kabupaten Way kanan, yang belum tinggi pula. Apabila hal tersebut di atas dikaitkan dengan laju PDRB Kabupaten Way Kanan sejak Tahun 2010 - 2020, berdasarkan PDRB perkapita atas dasar harga konstan tahun 2020, menunjukkan bahwa laju peningkatannya, hanya berkisar 3,88 persen per tahun.

Persoalannya, pembangunan dan pemeliharaan infrastruktur transportasi, sekarang belum memadai sehingga tingkat pertumbuhan PDRB pun belum meingkat sebagaimana yang diharapkan. Hal ini dapat dilihat dari kapasitas infrastruktur transportasi yang tidak memadai dan berkualitas. Jalan raya dari arah bandar udara sampai di pusat kota Kabupaten Way Kanan, masih terbatas karena sebagian belum ada pembatas jalan, trotoar, saluran air, dan lebar badan jalan yang tidak sama, padahal jalan tersebut merupakan salah satu koridor ekonomi di Kabupaten Way kanan. Disepanjang pada koridor tersebut adalah masih minimnya fasilitas penerangan sehingga menjadi salah satu penyebab seringnya terjadi kecelakaan di jalan.

Belum lagi, jika dihadapkan dengan kapasitas infrastruktur jalan yang terbatas, mengakibatkan seringnya pengangkutan di jalan terkendala juga. Jalan raya dalam Kabupaten Way kanan sudah mengalami macet pada titik-titik tertentu. Kemacetan diakibatkan karena tidak ada area khusus perparkiran, sehingga kendaraan diparkir pada sisi kiri dan kanan. Hal ini menyebabkan jalan-jalan menjadi sempit. Permasalahan lainnya, adalah jalan-jalan ke arah pedesaan ruas jalannya tidak lebar dan tidak berkualitas.

Infrastruktur pelabuhan darat pun mengalami hal yang tidak berbeda jauh dari kondisi kapasitas jalan raya. Kapasitas terminalnya relatif terbatas sehingga kendaraan angkut barang lambat karena area perputaran kenderaan di dalam sempit. Bongkar muat barang membutuhkan waktu yang cukup lama. Lapangan penumpukan barang (container) merupakan terminal pelabuhan untuk kendaraan bongkar muat. Begitu pula dengan kendaraan bongkar muat sering antrian yang cukup lama, akhirnya pengangkutan barang yang tidakdigudangkan dan langsung diangkut ke tempat tujuan menjadi terhambat. 
Sedangkan untuk infrastruktur bandar udara, hambatannya adalah kapasitas bandara udaranya terbatas, yaitu panjang landasan pacu kurang dari 3.000 meter. Kapasitas bandar udara Gatot Subroto, panjangnya hanya 2.500 meter, sehingga untuk penerbangan pesawat berukuran besar belum bisa untuk mendarat. Ukuran pesawat yang mendarat di bandar udara Gatot Subroto hanya ukuran kecil, dan pesawat ukuran kecil yang mendarat hanyalah dengan kapasitas penumpang maksimal 40 orang. Persoalan utama lainnya adalah pesawat propeller turbotrop belum bisa mendarat pada malam hari karena keterbatasan fasilitas pendukung pada landasan pacu (runway). Oleh karena itu, pesawat yang akan landing (mendarat) dan take-off di Bandar Udara Gatot Subroto - Way kanan, hanya sampai pada jam 15.00 WIB. Akibat yang akan ditimbulkan dari permasalahan-permasalahan tersebut, adalah terhambatnya arus mobilitas/distribusi barang dan orang ke tempat tujuan menjadi terhambat. Semua kendala-kendala kapasitas infrastruktur jalan, pelabuhan darat dan bandara udara tersebut, akan menciptakan efek/domino yang berantai.

Efek yang paling berpengaruh adalah terutama biaya pengangkutantinggi, berpengaruh padatingkat harga yang tinggi dan akhirnya harga tersebut dibebankan pada konsumen. Efek lanjutannya adalah daya beli masyarakat relatif rendah. Daya beli dari masyarakat yang rendah maka aktivitas ekonomi akan jadi mandek, dan seterusnya. Bila demikian, akan berpengaruh negatif terhadap pertumbuhan ekonomi bagi Kabupaten Way Kanan.

Berkaitan dengan itu, maka untuk kepentingan penelitian maka rumusan masalah yang dibangun meliputi: apakah pembangunan transportasi jalan, transportasi pelabuhan darat, dan transportasi udara berpengaruh signifikan terhadap Produk Domestik Regional Bruto di Kabupaten Way kanan. Sedangkan tujuan daripada penelitian ini adalah untuk menganalisis pembangunan transportasi jalan, transportasi pelabuhan darat, dan transportasi udara dapat mempengaruhi Produk DometikRegional Bruto di Kabupaten Way kanan ke depan. Karena itu, bila permasalah-permasalahan tersebut tidak dicari solusi pemecahannya secara serius maka akan berpengaruh negatif secara langsung pada kegiatan perekonomian termasuk pelayanan publik, baik dalam lingkup mikro mapun makro.

Dengan demikian, peneliti tertarik untuk meneliti tentang apakah pembangunan infrastruktur transportasi dapat mempengaruhi produk domestik regional bruto bagi Kabupaten Way kanan. Asumsi peneliti sementara bahwa, ketiga jenis infrastruktur transportasi tersebut merupakan faktor penentu dan paling berpengaruh dalam merangsang serta memacu laju produk domestik regional bruto yang signifikan.

\section{KAJIAN PUSTAKA}

Teori Dorongan Kuat (Big-Push Theory), yang menyatakan bahwa untukdapat menanggulangi hambatan pembangunan ekonomi atau mempercepat adanya perubahan suatu pembangunan kearah kemajuan diperlukan suatu dorongan kuat melalui prioritas pembangunan dibidang ekonomi melalui pembangunan infrastruktur lebih dahulu, perkembangan yang lain akan menetes mengikutinya (trickle down effect), sehingga pada akhirnyan pertumbuhan ekonomi akan meningkat secara signifikan. Dengan kata lain, setiap penambahan modal/capital dalam pembangunan infrastruktur akan diikuti pula dengan peningkatan output.

Bila dikaitkan dengan ruang lingkup penelitian ini maka adalah tepat jika dikaitkan dengan teori Sutami yang mengatakan bahwa pembangunan infrastruktur yang handal akan memberikan kontribusi ekonomis dalam penggunaan potensi sumber daya alam yang ada di kawasan tersebut sehinggga dapat berfungsi sebagai penggerak dalam pengembangan wilayah. Sejalan dengan itu, maka ketersediaan infrastruktur transportasi tentu memberikan efek multiplier bagi proses kegiatan ekonomi, baik dari segi proses produksi, bertumbuhnya sektor industri karena adanya peningkatan output pada semua sektor ekonomi, penciptaan lapangan kerja, pendistribusian barang dan jasa termasuk mobilitas penduduk/orang menjadi lancar yang pada akhirnya dapat meningkatkan nilai tambah dalam wujud PDRB.

Sebelum melangkah lebih jauh, maka ada baiknya perlu untuk memberikan batasan maupun lingkup daripada infrastruktur transportasi itu sendiri menjadi tiga kelompok, yaitu: 
infrastruktur keras fisik (physical hard infrastructure) adalah meliputi jalan raya, rel kereta api, bandara, dan pelabuhan, bendungan dan saluran irigasi, dan sebagainya; infrastruktur keras nonfisik (nonphysical hard infrastructure), adalah infrastruktur yang berkaitan dengan fungsi dan utilitas umum, seperti listrik, jaringan telekomunikasi (telepon, internet), pengolahan air dan jaringan pipa penyaluran, pasokan energi mulai dari minyak bumi, biodiesel, dan gas berikut jaringan pipa distribusinya, dan lainnya; dan infrastruktur lunak (soft infrastructure) atau biasa pula disebut kerangka institusional (kelembagaan) yang meliputi nilai (ternasuk etos kerja), norma (khususnya yang telah dikembangkan dan dikodifikasikan menjadi peraturan hukum dan perundang- undangan), serta kualitas pelayanan umum yang disediakan oleh berbagai pihak terkait, khususnya pemerintah.

Berdasarkan penjelasan diatas, maka yang dimaksud infrastruktur dalam penelitian ini adalah infrastruktur transportasi, yang meliputi: infrastruktur jalan (ways infrastructure), infrastruktur pelabuhan darat (dryport infrastructure), dan infrastruktur bandar udara (airtport infrastructure).

Didalam suatu wilayah yang ingin perekonomiannya cepat tumbuh, berkembang dan maju, biasanya yang paling didahulukan adalah pembangunan infrastruktur, salahsatunyaadalah infrastruktur transportasi, terutama jalan, pelabuhan, bandar udara dan kemudian yang lainnya. Dengan demikian diharapkan kehandalan infrastruktur yang ada di daerah berpengaruh positif dan signifikan dalam meningkatkan pertumbuhan ekonomi.

Disadari atau tidak, jalan adalah suatu jalur di daratan yang sangat vital demi keberlangsungan kegiatan perekonomian dan mobilitas dari suatu penduduknya. Tanpa infrastruktur jalan di suatu wilayah maka dipastikan suatu wilayah atau negara akan tetap dalam keadaan subsisten bahkan terbelakang di semua aspek kehidupan dan penghidupan, oleh karena hubungan dengan dunia luar tidak memungkinkan. Begitu vitalnya, infrastruktur transportasi jalan oleh karena merupakan sarana dan prasarana transportasi didaratanyang sekaligusmelayani jasa daripada infrastruktur pelabuhan darat dan bandar udara. Oleh sebab itu, bongkar muat barang/penumpang yang ada disediakan oleh jasa pelabuhan darat dan bandara udara untuk didistribusikan ke daerah tujuan sangat ditentukan oleh ketersediaan armada angkutan yang beroperasi di Kabupaten Way kanan.

Hal lainnya, bahwa transportasi jalan merupakan syarat mutlak didalam pengangkutan barang dan orang dari suatu tempat ke tempat tujuan. Transportasi jalan yang tidak handal maka moda transportasi di daratan sebagai jasa pengangkutan tidak mungkin dapat berlangsung dengan baik. Aksesibilitas jalan yang merupakan simpul- simpul/jaringan jalan yang terdiri dari jalan nasional, jalan provinsi maupun jalan kabupaten. Dengan demikian, moda transportasi yang ada sangat memudahkan mobilisasi barang/ jasa dan orang akan berjalan dengan lancar apabila didukung dengan transportasi jalan yang berkualitas.

Pelabuhan darat sangat dibutuhkan untuk tempat penampungan kontainer dalam berbagai ukuran dan jenisnya, karena itu pelabuhan darat sangat dipertimbangkan mengenai kapasitasnya sebagai tempat untuk melakukan bongkar muat barang. Selanjutnya, keberadaan daripada transportasi darat sangat dibutuhkan didalam mendistribusikan barang melalui perdagangan baik tataran regional, nasional maupun antar negara.

Perlu diketahui bahwa untuk mewujudkan kelancaran bongkar kontainer di pelabuhan darat, maka mutlak dibutuhkan prasarana dan sarana yang memadai dan perangkat yang sesuai dengan peradaban teknologi bongkar muat. Selain itu harus ada sinergitas antara prasarana dan peralatan bongkar muat barang dengan sarana dan/atau moda pengangkutan yang memadai serta ditopang oleh adanya area/ depot yang memungkin proses pengangkutan oleh moda transportasi darat untuk diteruskan ke tempat tujuan yang lain.

Bandar udara dapat diartikan sebagai tempatnya suatu pesawat untuk mendarat (landing) dan lepas landas (take-off) setelah menurunkan barang atau manusia untuk diangkut oleh moda transportasi ke tempat tujuan akhir maupun menaikkan manusia dan barang untuk 
selanjutnya diterbangkan ke tempat tujuan berikutnya secara cepat. Agar proses perpindahan pengangkutan dari pesawat ke moda transpotasi lainnya berjalan dengan efisien maka perlu didukung oleh sarana dan prasarana yang handal.

Transportasi udara mempunyai peranan yang sangat penting dalam menyediakan jasa pelayanan transportasi untuk pengangkutan manusia dan barang antara bandar udara yang satu dengan bandara yang lain ataupun perpindahan pengangkutan dari bandara ke moda transportasi darat untuk didistribusikan ke tempat tujuan melalui transportasi jalan/ daratan. Dan yang terpenting dari hadirnya transportasi udara adalah memberikan pelayanan pengangkutan yang sangat cepat dibandingkan dengan moda transportasi yang lain dan dapat melayani daerah-daerah terpencil atau terisolasi secara geografis serta dapat merangsang siklus kegiatan perekonomian di suatu kawasan tertentu.

Terkait dengan peran infrastruktur transportasi, salah satu pengaruhnya adalah pertumbuhan PDRB. Ada 3 (tiga) pendekatan yang dipakai didalam menghitung PDRB, yaitu pendekatan produksi, pendapatan, dan pengeluaran. Namun, pendekatan yang digunakan dalam penelitian ini untuk menghitung PDRB adalah pendekatan produksi. PDRB dengan pendekatan produksi meliputi: 1) pertanian, peternakan, kehutanan, dan perkebunan; 2) pertambangan dan galian; 3) industri dan pengolahan; 4) listrik, gas dan air bersih; 5) bangunan/konstruksi; 6) perdagangan, hotel dan restoran; 7) pengangkutan dan komunikasi; 8) keuangan, persewaan, dan jasa perusahaan; 9) jasa-jasa termasuk jasa pelayanan pemerintah. Secara empirik, membuktikan bahwa peran infrastruktur transportasi sangat mempengaruhi pertumbuhan PDRB.

\section{METODE PENELITIAN}

Metode penelitian yang digunakan dalam penelitian ini adalah metode kuantitatif, sedangkan alat analisis yang digunakan untuk menunjukkan adanya pengaruh variabel infrastruktur transportasi terhadap Produk Domestik Regional Bruto, adalah persamaan regresi berganda.

Berdasarkan model dasar tersebut, dengan memecah infrastruktur transportasi menjadi tiga variabel independen yang diteliti, yaitu 1) infrastruktur transportasi jalan; 2) infrastruktur transportasi pelabuhan darat; dan 3) infrastruktur transportasi bandar udara.

Alat analisis regresi berganda tersebut bertujuan untuk mengestimasi dan/ atau menganalisis pengaruh variabel-variabel independen terhadap variabel dependen. Dengan kata lain, alat analisis regresi berganda yang telah ditransformasi ke dalam logaritmanatural adalah bertujuan untuk menguji tiga hipotesis yang ada dalam penelitian ini.

Jenis data yang digunakan dalam penelitian ini adalah data Time Series. Data yang digunakan disini adalah meliputi data jumlah angkutan jalan, data jumlah kedatangan kontainer, dan data frekuensi kunjungan (penerbangan) pesawat.

Berkaitan dengan teknik analisis yang digunakan, maka hipotesis yang dibangun dalam penelitian tersebut, adalah:

H1: Diduga bahwa, pembangunan infrastruktur transportasi jalan berpengaruh signifikanterhadap ProdukDomestik Regional Bruto (PDRB).

H2: Diduga bahwa, pembangunan infrastruktur pelabuhan darat berpengaruh signifikan terhadap Produk Domestik Regional Bruto (PDRB).

H3: Diduga bahwa, pembangunan infrastruktur transportasi bandar udara berpengaruh signifikan terhadapProduk Domestik Regional Bruto (PDRB).

\section{HASIL DAN PEMBAHASAN}

Berdasarkan hasil regresi berganda dari pengaruh variabel infrastruktur jalan terhadap PDRB Kabupaten Way Kanan, menunjukkan bahwa hasil uji serentak/simultan (uji F) diperoleh Fhitung sebesar 54.294 dengan tingkat signifikansi 0,000. Berhubung nilai probabilitasnya adalah 0,000 berada jauh di bawah $\alpha=0,05$ sehingga model regresi tersebut dapat 
digunakan untuk memprediksi adanya peningkatan PDRB. Artinya, variabel jumlah angkutan jalan, kunjungan kontainer, dan frekuensi penerbangan pesawat secara simultan berpengaruh secara signifikan terhadap PDRB Kabupaten Way kanan. Sedangkan uji parsial (Uji t) adalah untuk menguji pengaruh variabel infrastruktur transportasi yang terdiri dari infrastrukturjalan, infrastruktur pelabuhan darat, dan infrastruktur bandar udara terhadap PDRB Kabupaten Way kanan. Syarat untuk mengambil keputusan menerima atau menolak suatu hipotesis diperlukan pengujian hubungan kausal dengan metode analisis regresi linear berganda, yaitu dengan cara membandingkan nilai probabilitas dengan taraf signifikan sebesar $\alpha=0,05$ (5 persen), dimana: 1) Jika probabilitas > 0,05 maka H0 diterima; dan 2) Jika probabilitas $<0,05$ maka $\mathrm{H} 0$ ditolak.

Berdasarkan hasil pada tabel coefficients pada kolom significance, dengan cara membandingkan nilai probabilitas sebesar 0,010 <0,05 maka H0 ditolak. Dengan demikian, dapat dikatakan bahwa variabel infrastruktur jalan secara parsial berpengaruh secara signifikanterhadap PDRB Kabupaten Way kanan. Temuan ini sejalan dengan teori, bahwa bila terjadi peningkatan penggunaan modal dalam bentuk investasi infrastruktur jalan tentu akan merangsang pertumbuhan output. Dengan kata lain, peran infrastruktur jalan melalui sektor pengangkutan memberikan andil yang besar didalam mendistribusikan barang dan orang secara efektif dan efisien. Karena itu, kapasitas infrastruktur jalan yang memadai dan berkualitas akan memperlancar arus migrasi moda transportasi (angkutan jalan) untuk mengangkut barang dan orang ke tempat tujuan secara cepat, aman dan efisien.

Apabila dikaitkan dengan panjang jalan dalam Kabupaten Way kanan adalah 1.056.647 meter, dimana dari sisi jenis permukaan jalan, sekitar 458.996 meter yang belum diaspal, sedangkan dari aspek kondisi jalan, jalan yang mengalami kerusakan ringan adalah sepanjang 447.456 meter, dan rusak berat adalah sepanjang 134.000 meter. Hasil tersebut menunjukkan bahwa infrastruktur jalan relatif baik, sehingga dapat memperlancar kegiatan pengangkutan barang/orang ke tempat tujuan serta dapat meningkatkan PDRB bagi Kabupaten Way kanan.

Syarat untuk menguji pengaruh variabel pelabuhan darat terhadap PDRB Kabupaten Way kanan adalah dilakukan dengan cara membandingkan nilai probabilitas 0,309 $>0,05$. Berdasarkan hasil perbandingan tersebut, dapat disimpulkan bahwa HO diterima. Artinya, variabel infrastruktur pelabuhan darat secara parsial belum berpengaruh secara signifikan terhadap PDRB Kabupaten Way kanan. Hal ini kemungkinan dapat terjadi karena: 1) data yang digunakan tidak sesuai dengan konteks persamaan tersebut; 2) kontribusi pendapatan dari retribusi di pelabuhan darat, ternyata kecil sehingga pengaruhnya terhadap pertumbuhan PDRB belum signifikan; 3) pendapatan dari sektor pajak/bea cukai merupakan kewenangan dari Pemerintah Provinsi dan Pusat.

Berdasarkan hasil pengamatan dan wawancara yang dilakukan dengan salah satu responden, mengatakan bahwa dari kapasitas infrastruktur pelabuhan darat yang ada masih terbatas, terutama lapangan penumpukan/depo dipelabuhan belum ada. Depo yang ada sekarang adalah sebenarnya untuk terminal kendaraan/peralatan bongkar muat kontainer dan angkutan kendaraan darat. Lapangan penumpukan container (Depo) menjadi over kapasitas sehingga menjadi terhambat dan berpengaruh terhadap frekuensi kunjungan kontainer. Hambatan-hambatan inilah menjadi penyebab infrastruktur transportasi pelabuhan darat belum meningkatkan PDRB bagi Kabupaten Way kanan.

Syarat untuk menguji pengaruh variabel infrastruktur transportasi bandara udara terhadap PDRB Kabupaten Way kanan adalah dilakukan dengan cara membandingkan nilai probabilitas $0,093>0,05$. Perbandingan nilai tersebut, dapat disimpulkan bahwa HO diterima. Hal ini berarti, variabel infrastruktur transportasi bandara udara secara parsial belum berpengaruh secara signifikan terhadap PDRB Kabupaten Way kanan. Hal ini dapat terjadi karena kontribusi pendapatan dari retribusi, ternyata sangat kecil. Sedangkan pendapatan dari sektor pajak dan bea cukai merupakan kewenangan dari Pemerintah Provinsi Lampung dan Pemerintah Pusat. Penyebab lainnya adalah fasilitas pendukung terutama approach lights di 
sekitar kawasan area landasan pacu (runway) dan fasilitas glide path masih terbatas sehingga pesawat tidak bisa mendarat di malam hari. Disamping itu, panjang landasan pacu (runway) masih terbatas (hanya $2.500 \mathrm{~m}$ ) sehingga pesawat yang berkapasitas daya muat besar tidak bisa mendarat dan hal ini berdampak pada belum mendongkrak PDRB bagi Kabupaten Way Kanan.

Berdasarkan hasil penelitian dari ketiga variabel independen ditemukan bahwa: Pertama, secara simultan infrastruktur transportasi yang paling tinggi pengaruhnya terhadap PDRB Kabupaten Way kanan, adalah infrastruktur jalan. Hal ini disebabkan karena infrastruktur jalan melalui sektor pengangkutan di jalan raya sangat berperan untuk mendistribusikan barang/orang secara efektif dan efisien. Argumen ini diperkuat dengan hasil koefisien regresinya adalah 0,437. Artinya, setiap penambahan 1 unit angkutan jalan di Kabupaten Way kanan akan menyebabkan peningkatan terhadap PDRB sebesar Rp 437.000. Kemudian disusul oleh infrastruktur pelabuhan darat dengan koefisien regresinya sebesar 0,146. Hal ini berarti setiap kunjungan kontainer, akan menyebabkan peningkatan PDRB Kabupaten Way kanan sebesar Rp 146.000. Sedangkan yang paling rendah pengaruhnya terhadap pertumbuhan ekonomi adalah infrastruktur bandara udara, karena koefisien regresinya hanya sebesar 0,036 . Artinya setiap penambahan 1 penerbangan pesawat akan meningkatkan PDRB Kabupaten Way kanan sebesar Rp 36.000.

Kedua, secara parsial infrastruktur transportasi pelabuhan darat dan transportasi udara belum mempengaruhi peningkatan PDRB Kabupaten Way kanan. Pada hal secara teoritik mengatakan ketersediaan transportasi yang memadai tentu akan berperan dalam meningkatkan PDRB terutama dari sektor jasa pengangkutan, namun tidak demikian. Hal ini dapat disebabkan karena barang dan jasa yang di angkut oleh transportasi darat lebih banyak didatangkan dari luar Kabupaten Way kanan, sedangkan jasa transportasi Bandar udara lebih cenderung mengangkut orang- orang dibandingkan dengan komoditi/barang. Dengan kata lain, masyarakat Kabupaten Way kanan adalah masyarakat yang relatif cenderung konsumtif, bukan masyarakat yang cenderung produktif.

\section{SIMPULAN DAN SARAN}

Berdasarkan hasil analisis data mengenai analisis pengaruh pembangunan infrastruktur transportasi terhadap Produk Domestik Regional Bruto (PDRB) Kabupaten Way Kanan diperoleh kesimpulan, sebagai berikut:

a. Pengaruh pembangunan infrastruktur jalan secara parsial berpengaruh secara signifikan terhadap PDRB Kabupaten Way kanan. Hal ini diperkuat dengan nilai probabilitas 0,010 $<0,05$. Dengan demikian, dapat disimpulkan bahwa H0 ditolak. Hal ini dikarenakan, kapasitas infrastruktur jalan yang ada dalam Kabupaten Way kanan memungkinkan mobilitas pengangkutan menjadi lancar, sehingga kegiatan ekonomi masyarakatmakin bertumbuh dan meningkat dari waktu ke waktu.

b. Infrastruktur pelabuhan darat secara parsial belum berpengaruh secara signifikan terhadap pertumbuhan ekonomi Kabupaten Way kanan. Hasil tersebut didukung oleh nilai probabilitas 0,309 > 0,05 yang berarti $\mathrm{H} 0$ diterima. Hal ini terjadi karena kontribusi retribusi dari infrastruktur pelabuhan darat, ternyata kecil sehingga belum berpengaruh terhadap PDRB Kabupaten Way kanan. Penyebab lainnya adalah masih terbatasnya prasarana dan sarana seperti depo dan moda bongkar muat, akibatnya waktu menunggu untuk bongkar muat kontainer menjadi lama sehingga frekuensi kedatangan kontainer tidak maksimal/meningkat.

c. Pengaruh infrastruktur bandara udara secara parsial belum berpengaruh terhadap PDRB Kabupaten Way kanan, karena nilai probabilitas 0,093 $>0,05$. Berhubung nilai probabilitas jauh lebih besar daripada $\alpha=0,05$ maka H0 diterima. Hal ini terjadi karena 1) pendapatan dari retribusi pelayanan bandar udara, ternyata kontribusinya kecil terhadap pembentukan PDRB Kabupaten Way kanan; 2) fasilitas pendukung (approach light, glide path dan panjang landasan belum 3.000 meter) infrastruktur bandar udara masih terbatas sehingga pesawat belum bisa mendarat di malam hari dan ukuran pesawat yang besar belum bisa mendarat 
sehingga berpengaruh terhadap frekuensi penerbangan pesawat.

Berdasarkan hasil kesimpulan di atas, maka peneliti memberikan saran-saran sebagai berikut: a. Pembangunan infrastruktur jalan masih sangat berpeluang untuk dapat meningkatkan Produk Domestik Regional Bruto (PDRB) Kabupaten Way kanan, maka Pemerintah (Pusat, Provinsi dan Kabupaten) didalam kebijakan pembangunan, kapasitas infrastruktur jalan perlu ditingkatkan secara proporsional. Demikian pula, terminal maupun area parkir disediakan agar mobilisasi kendaraan danarus angkutan barang menjadi lebih cepat serta aman.

b. Agar kapasitas infrastruktur pelabuhan darat berpengaruh secara signifikan terhadap PDRB Kabupaten Way kanan, maka pemerintah dengan pihak terkait supaya meningkatkan kapasitas depo dan fasilitas bongkar muat barang.

c. Agar infrastruktur bandar udara berpengaruh secara signifikan terhadap PDRB Kabupaten Way kanan, maka Pemerintah dan instansi terkait selaku eksekutor dilapangan perlu menambah panjang landasan pacu supaya pesawat berukuran besar dapat mendarat dan fasilitas approach lights dan glide path harus ditingkatkan kemampuannya sehingga pesawat dapat mendarat di malam hari.

\section{IMPLIKASI PRAKTIS / TEORITIS}

Implikasi kebijakan yang diharapkan setelah mempertimbangkan kesimpulan adalah: a. Untuk infrastruktur pelabuhan darat dan udara sangat dibutuhkan campur tangan dari Pemerintah untuk memaksimalkan prasarana dan sarana/peralatan bongkar muat yang mengikuti perkembangan teknologi pelabuhan darat sehingga jumlah kunjungan container tidak bergantung sistem antrian.

b. Bagi infrastruktur bandar udara agar kapasitas prasarana dan sarana/peralatan harus dioptimalkan agar frekuensi penerbangan pesawat meningkat.

c. Bila kedua infrastruktur transportasi tersebut menjadi perhatian serius maka akan meningkatkan nilai tambah (PDRB) bagiKabupaten Way kanan.

d. Selain itu, agar kontribusi infrastruktur transportasi bandar udara dan pelabuhan darat dapat meningkatkan PDRB Kabupaten Way kanan maka perlu ada kebijakan dalam pembagian hasil pendapatan berupa pajak dan/atau bea cukai kepada pemerintah Kabupaten Way Kanan.

e. Adapun kontribusi teoritis dari penelitian ini adalah berfungsi sebagai pengembangan ilmu pembangunan wilayah dimasa akan datang.

\section{KETERBATASAN DAN SARAN}

Keterbatasan dalam pelaksanaan penelitian ini tentunya belum sempurna dan ke depan perlu untuk selalu disempurnakan. Beberapa keterbatasan yang ada dalam studi ini antara lain: pertama, kelemahan dari metode penelitian itu sendiri. Namun kelemahan ini sudah dicoba ditutupi oleh penulis dengan melibatkan aparatur pemerintah dan pelaksana lapangan yang mengetahui kondisi yang terjadi di lokasi penelitian. Kedua, data pendukung akan profil wilayah Kabupaten Way Kanan terbatas, dimana tidak tersedia data dengan series (waktu) yang cukup panjang dan juga masih tidak lengkapnya data-data untuk setiap aspek. Penulis juga sudah mengupayakan semaksimal mungkin untuk melengkapi data-data yang diperlukan, namun masih dirasa kurang sempurna. Hal ini dikarenakan pengadministrasian dan pencatatan statistik di daerah yang dijadikan wilayah studi ini masih belum baik juga. Oleh karena itu, ke depan penulis berharap studi ini akan dilanjutkan dengan studi-studi sejenis yang lain dan dengan berbagai penyempurnaan di sana-sini, terutama di UPTD Dinas Perhubungan, UPTD Dry Port Way Kanan dan UPTD Bandar Udara Gatot Subroto Kabupaten Way Kanan, Provinsi Lampung. 


\section{DAFTAR PUSTAKA}

Adisasmita, S. A,( 2012). Penerbangan dan Bandar Udara, Penerbit Graha Ilmu, Yogyakarta.

Agenor, P.R., (2006). A Theory of Infrastructure-led Development, Discussion paper series, Number 038, Center for Growth and Business Cycle Research, Economic, Studies, University of Manchester, Manchester.

Banerjee, dkk, (2012). On The Road: Access To Transportation Infrastructure And Economic Growth In China, NBER Working Paper No. 17897. P 1 - 50.

Basri dan Munandar, (2009). Lanskap Ekonomi Indonesia, Kajian dan Renungan Terhadap Masalah-masalah Struktural, Transformasi Baru, dan Prospek Perekonomian Indonesia, Penerbit Kencana, Jakarta.

Ghozali, I., (2005). Aplikasi Analisis Multivariate Management dengan Program SPSS, Penerbit Universitas Diponegoro, Semarang.

Jinca, M. Y., (2011). Transportasi Darat Indonesia: Analisis Sistem \& Studi Kasus, Penerbit Brilian Internasional, Surabaya.

Maryaningsih, N., dkk., (2014). Pengaruh Infrastruktur Terhadap Pertumbuhan Ekonomi Indonesia. Buletin Ekonomi Moneter dan Perbankan. Volume 17, No 1, Juli 2014.

Prasetyo, Firdaus, (2009). Jurnal Ekonomi dan Kebijakan Pembangunan: Pengaruh Infrastruktur Pada Pertumbuhan Ekonomi Wilayah Di Indonesia, IPB, Bandung.

Putra, Adris A \& Djalanti S., (2016). Pengembangan Infrastruktur Pelabuhan Dalam Mendukung Pembangunan Berkelanjutan. Jurnal Ilmiah Media Engineering. Vol. 6 No. 1 Januari 2016.

Setiawan, Kusrini (2010). Ekonometrika: Analisis Regresi, Multikloneritas, Heteroskedastisitas, Otokorelasi, Sistem Persamaan Simultan, Model dinamis, Penerbit CV. Andi Offset, Yogyakarta.

Susantono, B., (2013). Transportasi \& Investasi: Tantangan dan Perspektif Multidimensi, Penerbit PT. Kompas Media Nusantara, Jakarta.

Tusmar, T \& Mora, M., (2015). Perkembangan Perekonomian Wilayah dan Kargo Udara: Korelasiatau Kausalitas.Jurnal Perhubungan Udara: Warta Ardhia, Vol. 41 No. 1, Hal. 39 - 48. Jakarta.

\section{Profil Penulis}

Febriansyah dan Gustaf Gautama adalah dosen pada program studi Manajemen dan program studi Teknik Sipil pada Universitas Sang Bumi Ruwa Jurai Lampung. Pengalaman selain sebagai seorang dosen, peneliti juga sebagai seorang pemerhati pembangunan infrastruktur serta entrepreneur yang aktif dalam pengembangan usaha UMKM. Topik penelitian yang digeluti diantaranya entrepreneurial marketing, pembangunan infrastruktur, social marketing, dan Business Law. Penulis dapat dihubungi melalui email: febriansyahali9@gmail.com. 